\title{
Library automation and Open source software in Italy: an overview.
}

\section{Giovanna Frigimelica and Andrea Marchitelli ${ }^{1}$}

The notions of information technology and procedure automation start to circulate within Italian libraries at the end of the 60s, when the first software products were released for that use.

The turning point was 1968, as an effect of a tragic event in Italian history: the flood of Florence in 1966. In October 1968 a seminar was held in Florence in order to present the results of two studies carried on in the framework of the aids from ALA to Italian libraries: John Finzi from Library of Congress, and Joseph Becker of EDUCOM dealt with the possibilities to reorganize in a new way the services offered by the Central National Library of Florence.

The conclusions of the seminar were various, the first of whom was a study on information technologies and the formal usage of the MARC standard, with the program ANNA 2.

In a short time, "Biblio" project started; in order to support the automation of the Central National Library of Rome.

In the same years the university consortia, born for supporting supercomputing, at the beginning, started to hold a relevant role in university library automation.

Although the automation of BNI (Italian National Bibliography) has been an important step in the process of library automation, the process didn't have direct practical consequences, because the Italian library system itself, lacking in real catalographic cooperation, considered BNI an authoritative source for catalographic control rather than for derived cataloguing. ${ }^{3}$

In the 70s the experimentation involves documentation centres of important research institutes such as CNR (National Research Council), CNEN, and ISS (National Institute for Health). ${ }^{4}$ These experiences share the attention to internal procedures, such as acquisition and cataloguing, rather than services to users, such as document circulation. This choice of principle - caused by precise planning and scarce funds, will have as a consequence the constant delay of services to the public.

\footnotetext{
${ }^{1}$ Giovanna Frigimelica, AIB, Associazione Italiana Biblioteche, frigimelica@ aib.it; Andrea Marchitelli, CILEA, marchitelli@cilea.it

${ }^{2}$ In 1975 the annual BNI (the Italian National Bibliography) catalogue was producted on a magnetic tape; this is the first electronic processing of bibliographic data in Italy.

Data was registered in a format resulting from modifications of both MARC II and UKMARC, ANNAMARC

(Automazione Nella NAzionale, i.e. "National Library Automation"). BNI was published in that format until 1984, when started the use of UNIMARC.

${ }^{3}$ Weston, P.G., 2001. Catalogazione bibliografica: dal formato MARC a FRBR. "Bollettino AIB", 41(3), $267-286$.

${ }^{4}$ Carosella, M.P. and Valenti, M., eds, 1973. Progetti di automazione nelle biblioteche italiane. Roma: AIB.
} 
At the end of the 70s a cooperation project at a national level appears, giving the basis for the interlibrary loan service, SNADOC, which is the precedent of SBN, the Italian National Library Service.

The project, based on the idea of creating a cooperative "service" ambitiously aimed to create "a new drawing of the Italian library situation" ${ }^{\prime 5}$ rather than to rationalize the internal management procedures.

The elaboration of SBN starts in 1980 - with further thoughts strongly criticized in 1985, while the system sees the light in 1992 when the two Central National Libraries (Rome and Florence) enable the connection to the Index processor, at the hearth of the information architecture ${ }^{6}$.

In the last years the technological changes have been so radical that the Index appeared to be dated, a real legacy in the prevailing client-server software framework.

However, SBN could not bridge the delay: the decision in 2004 to create a client-server system Unix-based was accomplished in 2009, when a client-server architecture left space to web-based architectures.

The creation of SBN and its specific characteristics have been playing an important role in Italian software market. The technological choices resulting from a feasibility study on SBN devolved by Italsiel and Geac, including the usage of an IBM platform to manage the Index, and the utilization of SNA net protocol rather than ISO/OSI standard, caused a closure of the system both on the structure of bibliographic data, on the hardware and communication protocols, and on conversation between the Index and the Poles.

Some italian regions, as Lombardia, Piemonte and Emilia-Romagna had a lead role in SBN growth, funding the development of software packages, the management of which they entrusted to completely or partially private businesses (CSI Piemonte, Lombardia Informatica, Celcoop Ravenna), with the addition of Italsiel, creating a protected market without competition.

\footnotetext{
${ }^{5}$ Crocetti, L., 1986. Relazione introduttiva, La cooperazione: il Servizio Bibliotecario Nazionale. Atti del 30. Congresso Nazionale della Associazione Italiana Biblioteche, 21-24 novembre 1982 1986, Università di Messina.

${ }^{6}$ The information component of SBN has been designed between 1980 and 1985, with the aim of creating two main services: the access to documents through a common catalog of bibliographic resources of the main Italian libraries, and a national service for document circulation and loan. Both services are satisfied with the presence of a specific machine called "Index", which contains the basis elements to check a bibliographic notice and to address a specific request (loan, copy of a bibliographic record) to the most suitable library or database. Moreover, libraries belong to local sistems called "Poles", connected to the Index. The connection iss keeped working with the same procedures, even though sometimes based on different hardware. This solution respected the charatcteristics of the Italian market, divided into IBM; Olivetti, controlled by Carlo De Benedetti since 1978; Honeywell, who bought out the information activities of General Electrics in 1970 - including the Italian partner that became HISI (Honeywell Information Systems Italia), then Honeywell-Bull, and Bull at the end; Sperry, bought by Burroghs 1986 becoming Unisys Corporation.

[Leombroni, C., 2003. Una vicenda controversa: l'automazione delle biblioteche in Italia, A. Petrucciani and P. Traniello, eds. In: La storia delle biblioteche: temi, esperienze di ricerca, problemi storiografici, $16-17$ settembre 2002 2003, AIB pp167-196.]
} 
After an agreement between the Italian State and these regions, ${ }^{7}$ the software could be used for free by other regions who asked for it.

Three are the consequences of this choice: ${ }^{8}$

1. the absence of a real competition blocked the proper development of a national market

2. a separation of the institutional policies of a public organization from the commercial ones of the related private business became impossible

3. the immobilism of market and the impossibility to choose freely between concurrent software disturbed the development of quality software, limiting many Italian private business to the role of integrating gaps and lacks of legacy software SBN.

In order to solve these problems and to adjust SBN to the current technologies, in 1996 ICCU entrusted Etnoteam to make a feasibility study on the evolution of SBN. ${ }^{9}$

The project "Evolution of SBN Index" had three main objectives:

- technological renewal of Unix-based hardware and software, use of TCP/IP protocol and of middleware market standard, object-programming, use of XML and UNICODE.

- rationalization, integration, and structuring of database

- opening of the SBN Index to non-SBN library systems using the most common bibliographic format, such as UNIMARC, MARC21, with the help of a standard interface allowing developers to provide other software a conversation with the Index

- management of different cooperation levels: each Pole could choose its own level of participation to SBN (data collection, location of possessed material, insertion of new catalographic descriptions, correction)

- development of new features, such as derived cataloguing (the possibility to import bibliographic data from different databases), batch import (dump of bibliographic archives previously built with comparison of data).

The first part of the project ended in February, 2004, with the activation of Index2 SBN. From that time, the certification of software from different producers started: a certification of data flow and data stream between that applications and SBN Index is now required. This fact undoubtedly shook ILS Italian market, keeping SBN at the core of the interests of developers with an out-and-out running to certification.

\footnotetext{
${ }^{7}$ Istituto Centrale per il Catalogo Unico e le informazioni bibliografiche, 1988. Convenzione tra il Ministero per i Beni e le Attività Culturali - tramite l'Istituto Centrale per il Catalogo Unico - e le Regioni Emilia-Romagna, Lombardia e Piemonte per lo scambio dei software SBN e la concessione in uso dei software medesimi alle altre Regioni o ad altri soggetti.

${ }^{8}$ Leombroni, C., 2003. L'automazione delle biblioteche italiane e l'SBN. "Economia della Cultura. Rivista dell'Associazione per l'Economia della Cultura", (3), 335-342.

${ }^{9}$ Cerone, F. and Molfese, S., 1998. Studio di fattibilità sull'evoluzione della rete SBN. "SBN Notizie”, 1.
} 
SBN strongly influenced library automation market, creating a dichotomy between SBN libraries and non-SBN libraries. Until 90s (but still nowadays in some small realities), different automation systems coexisted in the same library to manage different activities. Both International and locally developed software found a niche in the marketplace, offering tools to libraries that allowed the development of services to patrons different from SBN (in which great attention had always been paid to the cataloguing process).

The economic factor influenced this area: due to the scarce economic resources for libraries, developments had always been limited, market still, and the diffusion of advanced and expensive software narrowed.

The usage of open source software for library management concerns few libraries at the moment, and there is not a movement for the promotion of this school of thought. A study of April $2009^{10}$ underlines that about twenty Italian libraries use open source library automation systems, against 15000 libraries in Italy.

PMB counts 13 installations, Koha 2, while Openbiblio only 1. Two more open source software for OPAC developed in Italy, Jopac2 and Pico, are available. The libraries using OS library automation systems belong to private organizations, to schools or to the Church; these libraries are the weak link within the National system, which is very complex due to the fact that a variety of bodies manage it. ${ }^{11}$ Libraries using OS automation system receive no funding at all or have an inadequate budget, and usually their information and cultural function is not clearly recognized by the management of the Institution they belong to.

The diffidence towards open source in Italian libraries is now usually due to the fact that these products are unreliable and without a solid distributor or vendor on its back. But in the history of library automation in our Country we can find some important and well known examples of software developed without distributors, and attempts to elaborate native open source software or to release the sources of proprietary software.

CDS/ISIS, a software developed and freely distributed from UNESCO (in collaboration with many other organizations) starting from 1985, is distributed In Italy by DBA Association. In 2004, DBA declared 1800 distributions against 1500 of the previous year ${ }^{12}$. Obviously, a distribution does not mean an active and working installation, but CDS/ISIS has been used by many public libraries, thanks to ad-hoc applications made for the management of library processes.

\footnotetext{
${ }^{10}$ G. Frigimelica, "La diffusione di software Open Source per la gestione di biblioteche in Italia". "Biblioteche oggi", 2009, vol. 27, n. 6, p. 37-43, <http://eprints.rclis.org/17095/>

${ }^{11}$ Guerrini Mauro. Libraries in Italy: a brief overview ; with the collaboration of Giovanna Frigimelica. "IFLA Journal", 35 (2009), n. 2, p. 94-116.

${ }_{12}$ Bertini Vanni. Rapporto sui sistemi di automazione in Italia 2005-2007, in Rapporto sulle biblioteche italiane $2007-$ 2008, a cura di Vittorio Ponzani, Roma, AIB, 2009, p. 115-127.
} 
The only Italian project for an open source ILS is DAFNE, born in 1999 within the provincial library system of Rovigo (Northern Italy). The source had never been released. ${ }^{13}$

@UOL is another example: created in 1990 at the National Library of Florence with the partnership of Bassilichi, in 2005 was announced that its source files would be made available with a LGPL licence - copyleft on single files, not on the whole software. As of now, one organization only asked for the source files, despite the usage of @UOL in the whole national territory (645 libraries, 8 library systens with 359 libraries with @UOL installations in 2007) ${ }^{14}$. The library system of the province of Bergamo (216 libraries) asked for the source files and, with the help of the Polytechnic Innovation Consortium of Milan (now Alintec) created a new proprietary software called BEvolution.

The Italian projects dedicated to open source software development for library automation are two, both focusing on data publication into an OPAC: Jopac, and Pico.

JOpac2 starts to be developed in 2000 by Romano Trampus and Albert Caramia. Due to their experience at the University of Trieste, Technology for Libraries dept., they decided to create an open source software on a framework that make easy to integrate data from different sources and to display them in different ways. ${ }^{15}$

PicO (Primary Interface for Opac) is a tool for OPAC building created by CILEA on the basis of the software "wwwisis", web environment of CD/ISIS. Its distribution is under a GNU GPL licence. $^{16}$

Italy lacks a movement in favour of open source ILS: the few Italian projects seen before were not supported by Institutions, they had often been completed without proper support and discouraging the collaboration of the Professional community (for example, by putting limits such as the need to ask for source files). Even in the professional literature we can find only a few articles about ILS open source. ${ }^{17}$ These facts reflect the scarce interest towards the diffusion of the open source movement in Italian libraries.

\footnotetext{
${ }^{13}$ Sturman Robi. Il software open source per la gestione integrata delle biblioteche: una nuova risorsa?, "Bollettino AIB", 44 (2004), 3, p. 257-270, <http://www.aib.it/aib/boll/2004/0403257.htm>

${ }^{14}$ BERTINI, cit.

${ }^{15} \mathrm{http}: / / \mathrm{www}$.jopac2.org/

${ }^{16} \mathrm{http}: / /$ www.cilea.it/index.php?id=931

${ }^{17}$ Only 4 articles can be found in the Italian professional literature: FRIGIMELICA cit., STURMAN cit., DI GIAMMARCO Fabio. Open source e biblioteche: un incontro possibile. "Biblioteche Oggi" vol. 26 (2005) n. 1, p. 6869; BALDI Paolo. Il bibliotecario e l'open source. "Bibelot", a. 11 (2005) n. 2,

$<$ http://www.aib.it/aib/sezioni/toscana/bibelot/0502/b0502b.htm>
} 
If we have a look to what happens outside Italy, we can see that in United States in 2007, open source contracts represented the $10 \%$ of the ILS contracts for academic and public libraries. ${ }^{18}$ In Belgium 51 libraries use an open source ILS among more or less 500 existing (i.e. the $10 \%) .{ }^{19}$ In France every three libraries one chooses an open source ILS. ${ }^{20}$

In the two-year period 2006-2008 a few Italian library systems faced a re-computerization choosing a proprietary software. The reasons for the choice of proprietary software rather than open source ones, as reported during informal talks by colleagues involved, were: the OS product is unsettled; open source software means strong reliance on systems and information engineers.

The adoption of open source software for library automation can respond, finally, to an Instruction issued by the Italian Minister of Innovation and Technologies on December 19, 2003 on "Development and use of information software for Public Administrations": Public Administration should prefer information software not deriving from a sole supplier or proprietary technology.

CILEA, one of most important Italian Academic Consortium for library automation, started distributing Koha in this end of 2009. Koha is one of most known open source ILS and it is used by important libraries worldwide. It will be interesting to see how the Italian professional community will respond to this new product. Since the lack of economic resources is something chronic in Italian libraries, we think that the present economic crisis will not bring libraries attention towards open source systems.

We need a cultural and managemental change: Italian libraries should plan their automation choices in a different way.

\footnotetext{
${ }^{18}$ BREEDING Marshall. The Viability of Open Source ILS, "Bulletin of the American Society for Information Science and Technology", 35 (2008), 2, p. 20-25, <http://www.asis.org/Bulletin/Dec-08/DecJan09_Breeding.html> ${ }^{19}$ Chalon, Patrice X., MELON Pascale. Les SIGB libres en Belgique: état des lieux et analyse, "Cahiers de la documentation = Bladen voor documentatie" 2008/2, <http://eprints.rclis.org/14411/1/chalon-melon_2008.pdf> ${ }^{20}$ Maisonneuve Marc, Bibliothèques, l'équipement informatique en 2008, "Livres Hebdo", 767 (2009), p. 74-80, $<$ http://www.livreshebdo.fr/cache/upload/pdf/enquete_tosca_2008.pdf>.
} 